\title{
Penguatan Industri Jamu Herbal dalam Meningkatkan Nilai Ekonomi dan Kesehatan Ternak Ayam Pedaging
}

\author{
(Strengthening In Herbal Jamu Industri Improving Economic And Value \\ Chicken Animal Health) \\ Adi Sutanto $^{1}$, Wahyu Widodo ${ }^{2}$, Imbang Dwi Rahayu ${ }^{3}$, Tri Sakti Handayani ${ }^{4}$, \\ Apriliana Devi Anggraeni ${ }^{5}$ \\ 1,2,3,5 Jurusan Produksi Ternak, Fakultas Pertanian Peternakan \\ ${ }^{4}$ Jurusan PGSD, Fakultas Keguruan dan Ilmu Pendidikan \\ Universitas Muhammadiyah Malang, Jln. Raya Tlogomas 246 Malang.
}

\section{ARTICLE INFO}

Article history

Received : 30 October 2020

Revised : 15 November 2020

Accepted : 10 December 2020

DOI :

http://dx.doi.org/10.33366/jast.v4i2.2079

Keywords

herbal medicine;

chicken livestock;

canvas model

*e-mail corresponding author : sutanto@umm.ac.id

\section{(i) (2)}

This is an open access article under the Creative Commons Attribution-ShareAlike 4.0 International License. Any further distribution of this work must maintain attribution to the author(s) and the title of the work, journal citation and DOI. CC-BY-SA

\section{ABSTRACT}

The phenomenon of a healthy lifestyle or the back to nature movement has developed. An organic-based livestock production system, such as organic meat and eggs, which are herbal products, in principle, form natural immune support in livestock. Herbal products are currently considered safe for livestock and human health. They are formulated in the form of herbs; one of them has been developed herbal medicine with the brand Siyuna produced by the Department of Animal Husbandry, University of Muhammadiyah Malang, and applied to broilers. The method of implementation in this herbal medicine application uses an experimental approach, the implementation of industrial products, social product socialization, and commercialization using the canvas model, which is also carried out at the University of Muhammadiyah Malang, precisely in the close house research cage and also applied in Malang and its surroundings. The conclusion is that the use of herbal medicine by 1 percent is the right decision to support the sword chicken business's success in an economic and health review based on herbal medicine with the Siyuna brand.

\section{PENDAHULUAN}

Ketahanan pangan untuk manusia dan pakan untuk ternak, perlu perhatian serius karena sampai sekarang Indonesia masih rentan mengalami destabilasasi di bidang tersebut, secara khusus untuk bidang peternakan yang perlu perhatian serius adalah ketahanan pakan unggas. Sampai saat ini, ternak unggas masih membutuhkan ketersediaan pakan yang sebagian besar masih diimpor, termasuk jamu sebagai bahan pakan tambahan [1]. Bahan pakan tambahan yang merupakan warisan budaya tradisional di Indonesia sering disebut jamu tersebut, adalah obat tradisional yang dikenal khususnya bagi masyarakat Jawa dan Madura. Jamu 
sebagai potensi lokal dapat dijadikan alternatif green product pengganti obat yang berharga murah dan aman serta bebas bahan kimiawi berbahaya. Memperhatikan peran strategis pada aspek ketahanan pangan dan pangan sebagaimana tersebut di atas, kegiatan pengabdian ini mendasarkan aplikasi penggunaan jamu herbal pada ternak khususnya ayam pedaging, yang tujuannya untuk menadapatkan nilai tambah pada aspek ekonomi dan kesehatan [2],[3].

Jurusan Peternakan Universitas Muhammadiyah Malang (UMM) mempunyai banyak karya intelektual civitas akademika yang tidak ditindaklanjuti. Salah satu yang perlu dikembangkan karya penelitian jamu herbal organik dengan memanfaatkan program PPUPIK. Solusi yang diperlukan adalah: mengembangkan unit profit usaha pembuatan jamu herbal organik untuk ternak guna meningkatkan pendapatan Laboratorium Peternakan UMM melalui unit usaha pembuatan jamu herbal organik untuk ternak, meningkatkan ketrampilan dan pengalaman kerja kepada mahasiswa Namun demikian penguatan program ini tidak terlepas dari aspek komersialisasi inovasi yang dikembangkan, dengan demikian perlu dikaji terkait aspek atau nilai ekonomi dan kesehatan usaha ternak ayam pedaging yang semakin besar diharapkan kebeeradaanya dalam mendukung keberhasilan usaha.

\section{METODE KEGIATAN}

Kegiatan ini dilaksanakan di Universitas Muhammadiyah Malang, dan pelaksanaannya didasarkan atas aplikasi jamu herbal untuk ternak dengan merk Siyuna yang diproduksi Jurusan Peternakan UMM, kegiatan ini menggunakan pendekatan eksperimen, implementasi produk industri, dan pemasyarakatan produk komersial Siyuna. Komersialisasi inovasi jamu herbal yang telah dilaksanakan beberapa tahun sebelumnya. sampai dengan tahun 2019 tepatnya bertempat di kandang closed house Universitas Muhammadiyah Malang. PPUPIK ini merupakan hilirisasi dan komersialisasi capaian penelitian yang telah dilakukan. Metode pelaksanaan dalam kegiatan ini, secara khusus berorientasi pada aktivitas usaha berbasis agribisnis, yang meliputi aspek atau bidang produksi, pemasaran dan kerjasama kelembagaan, dengaan uraian sebagai berikut: 1) Bidang Produksi, dengan kegiatan pemilihan bahan baku, proses pembuatan jamu, pengemasan maupun penyimpanan dengan standart kualitas yang baik. Pengujian bahan dan produk jadi dilakukan pada laboratorium pakan ternak di Universitas Muhammadiyah Malang. 2) Pemasaran, potensi pemasaran produk jamu ternak melalui program PPUPIK ini cukup luas misalnya dosen dan mahasiswa merupakan konsumen utama serta kerjasama penelitian terkait khususnya di lingkungan kampus. Sistem pemasaran juga dilakukan dengan memperluas jaringan pemasaran melalui media social, dengan menggunakan facebook, Instagram maupun tergabung dalam media online shopee dan tokopedia.3) Kerjasama kelembagaan sangat efektif dalam optimalisasi kegiatan PPUPIK ini, yang didukung oleh beberapa pemangku 
kepentingan yang selama ini telah terjalin kerjasamanya [5].

Prinsip-pronsip dasar yang digunakan dalam industri jamu herbal untuk ternak ini, mengacu pada konsepsi agribisnis, dalam kajian teoritis merupakan suatu kelompuk industri pada bidang pertanian atau juga layanan yang dibutuhkan di dalam pertanian yang menjalankan usahanya berdasarkan prinsip komersial, terutama itu menggunakan teknologi canggih. Agribisnis dalam cara pandang ekonomi ialah suatu usaha dalam mempelajari strategi untuk dapat memperoleh keuntungan dengan melalui pengelolaan aspek budidaya, penyediaan bahan baku, pasca panen, proses pengolahan hingga masuk ke tahap pemasaran.

Adapun tahapan yang dilakukan dalam industri jamu herbal ini meliputi aspek:

- Bahan Baku dan ketersediannya

- Proses Produksi

- Produksi dengan sarana dan prasaranya

- Produksi dengan sarana dan prasaranya

- Manajemen

- Pemasaran
Alur proses Produksi PPUPIK Jamu Herbal Jurusan Peternakan Universitas Muhammadiyah Malang (UMM) ini digambarkan berikut.

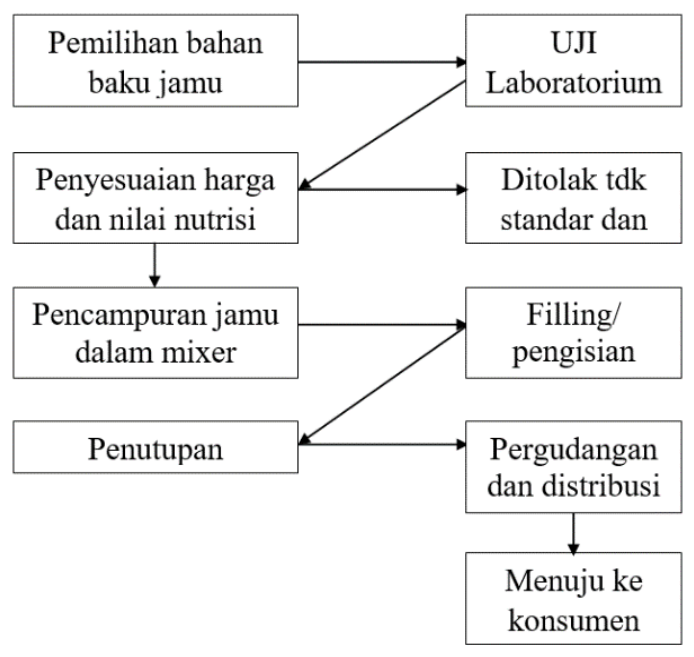

Gambar 1. Diagram alir produksi jamu

Luaran atau output dan dampak yang dihasilkan (outcome) dikaji dengan pendekatan Model Bisnis Canvas (BMC). Pendekatan BMC merupakan salah satu alat bantu pendekatan yang dapat digunakan untuk mendiskripsikan dan memanipulasi model bisnis dengan mudah dan sederhana. Analisis Model BMC yang menggunakan sembilan elemen kunci [4],[5].

Tabel 1. Manajemen Pembuatan Jamu Herbal untuk Ternak

\begin{tabular}{|c|c|c|}
\hline Periode Pengolahan Bahan Baku & Periode Pengolahan Jamu & $\begin{array}{l}\text { Periode Pengemasan dan } \\
\text { Penyimpanan }\end{array}$ \\
\hline $\begin{array}{l}\text { A. Persiapan (Preparing period) } \\
\text { a. Proses pencucian dan } \\
\text { sterilisasi } \\
\text { b. Mempersiapkan pemanas } \\
\text { c. Memasang alat penggiling } \\
\text { bahan baku } \\
\text { d. Mempersiapkan } \\
\text { kebutuhan pemanasan }\end{array}$ & $\begin{array}{l}\text { A. Mengatur kapasitas } \\
\text { produksi jamu } \\
\text { B. Persiapan Peralatan } \\
\text { pembuatan jamu } \\
\text { a. Tempat penggilingan } \\
\text { b. Tempat pencampuran } \\
\text { c. Peralatan lainnya } \\
\text { C. Pembuatan jamu yang tepat } \\
\text { a. Jenis bahan baku } \\
\text { b. Kandungan Nutrisi } \\
\text { dalam jamu } \\
\text { c. Kandungan zat aktif } \\
\text { dalam jamu }\end{array}$ & $\begin{array}{l}\text { A. Sebelum Pengemasan } \\
\text { 1. Membuat jadwal } \\
\text { pengemasan jamu setiap } \\
\text { hari } \\
\text { 2. Mempersiapkan peralatan } \\
\text { pengemasan jamu seperti } \\
\text { timbangan, alat tulis, surat } \\
\text { jalan, nota timbang, dll } \\
\text { 3. Membuat laporan secara } \\
\text { berkala }\end{array}$ \\
\hline
\end{tabular}




\begin{tabular}{|c|c|c|}
\hline $\begin{array}{l}\text { B. Persiapan selama periode } \\
\text { pemanasan (Cooking Period) } \\
\text { a. Menyalakan pemanas } \\
\text { b. mengontrol temperatur } \\
\text { c. mengecek kualitas bahan } \\
\text { baku jamu } \\
\text { d. mengontrol keadaan } \\
\text { pemanas } \\
\text { e. melakukan seleksibahan } \\
\text { baku jamu } \\
\text { f. Melakukan pemanasan } \\
\text { yang benar } \\
\text { Melaksanakan program produksi } \\
\text { secara benar }\end{array}$ & $\begin{array}{ll}\text { D. } & \text { Mengatur Keadaan } \\
\text { lingkungan } \\
\text { E. Mengatur pencampuran } \\
\text { F. Mengatur temperatur } \\
\text { produksi } \\
\text { G. Melaksanakan Program } \\
\text { Biosecurity } \\
\text { H. Pengontrolan pembuatan } \\
\text { jamu } \\
\text { a. Berat setiap } \\
\text { pencampuran jamu } \\
\text { b. Komposisi campuran } \\
\text { jamu }\end{array}$ & $\begin{array}{l}\text { B. Ketika Pengemasan } \\
\text { diklasifikasikan bahan jamu } \\
\text { untuk produksi tertentu } \\
\text { C. Pasca Panen } \\
\text { Menimbang jamu yang } \\
\text { tersisa dan mencatat total } \\
\text { jamu selanjutnya melakukan } \\
\text { perhitungan } \\
\text { Melakukan pengemasan dan } \\
\text { penyimpanan dalam gudang }\end{array}$ \\
\hline
\end{tabular}

\section{KARYA UTAMA}

Pencapaian program dalam penguatan industri jamu herbal untuk ternak ayam pedaging dalam meningkatkan nilai ekonomi dan kesehatan, ditunjukkan dalam matrik Tabel 2.

\subsection{Value Propositions}

Pakan dan jamu organik cenderung mempunyai keunggulan untuk dikembangkan oleh peternak khususnya ayam pedaging karena berbahan alami dan mudah untuk didapatkan, hal inilah yang merupakan keunggulan dari kombinasi penggunaan pakan dan jamu herbal organik. Akan tetapi baik pakan maupun jamu herbal organik kurang mendapatkan respon peternak karena kesulitan untuk mendapatkan bahan baku, harga yang relatif tinggi maupun sulit untuk mendapatkannya. Aspek kesehatan yang menjadi dasar proposisi nilai ini didasarkan atas indeks produksi usaha ayam pedaging, hal ini merupakan parameter mengukur keberhasilan pemeliharaan ternak unggas. [12]

Indeks Produksi yang didapatkan untuk usaha ayam pedaging tanpa menggunakan jamu (P0), menggunakan jamu 1, 2 dan 3 persen (P1, P2 dan P3) secara berurutan didapatkan nilai sebesar 390,3; 395,0; 401,6 dan 370,5 dengan demikian P2 memberikan nilai pemeliharaan kesehtan yang tinggi diikuti P1, P0 dan P3, kondisi yang demikian sudah baik karena dengan capaian lebih dari 350 yang secara umum dijadikan dasar penilaian.

\subsection{Customer Segments}

Target konsumen maupun segmen pasar sifatnya terbatas, upaya untuk menawarkan kepada kelompok konsumen yang yang lain tidak mungkin untuk dilakukan karena produksi yang dihasilkan relative terbatas karena belum ada kepastian pasar dalam artian potensi pasar masih relative kecil. Pemanfaatan obat-obatan tradisional sebagai langkah untuk mengurangi penggunaan obatobatan modern yang harganya relatif mahal, minat masyarakat untuk memanfaatkan kembali kekayaan alam sebagai ramuan obat seperti yang dilakukan pada jaman dulu yang semakin meluas, tidak hanya untuk manusia tapi sudah merambah ke dunia peternakan dan tidak terkecuali ternak unggas, khususnya ayam pedaging. [8][9] 
Tabel 2. Model Bisnis Canvas Jamu Herbal Ternak Ayam Pedaging

\begin{tabular}{|c|c|}
\hline Elemen Kunci & $\begin{array}{c}\text { Jamu Herbal untuk Ternak } \\
\text { Ayam Pedaging }\end{array}$ \\
\hline $\begin{array}{l}\text { a. } \text { Value } \\
\text { proposition }\end{array}$ & $\begin{array}{ll}\text { - } & \text { Alami } \\
\text { - } & \text { Sehat } \\
\text { - } & \text { Mudah didapat }\end{array}$ \\
\hline $\begin{array}{l}\text { b. Customer } \\
\text { Segments }\end{array}$ & $\begin{array}{ll}\text { - } & \text { Terbatas } \\
\text { - } & \text { Masyrakat luas }\end{array}$ \\
\hline c. Channels & $\begin{array}{l}\text { - Langsung } \\
\text { - } \text { Tidak langsung } \\
\text { - } \text { Media online } \\
\text { - } \text { Menggunakan alat-alat } \\
\text { pasar }\end{array}$ \\
\hline $\begin{array}{ll}\text { d. } & \text { Customer } \\
& \text { relationship }\end{array}$ & $\begin{array}{ll}\text { - } & \text { Spesifik } \\
\text { - } & \text { Ekonomi motif }\end{array}$ \\
\hline e. Key resource & $\begin{array}{l}\text { - SDM, sarana prasarana } \\
\text { dan teknologi terbatas }\end{array}$ \\
\hline f. Key activities & $\begin{array}{l}\text { - Dukungan penelitian } \\
\text { yang dinamis dan } \\
\text { signifikan }\end{array}$ \\
\hline g. Key partners & - Terbuka luas \\
\hline h. Cost Structure & $\begin{array}{l}\text { - Teridentifikasi secara } \\
\text { spesifik }\end{array}$ \\
\hline $\begin{array}{l}\text { i. Revenue } \\
\text { stream. }\end{array}$ & $\begin{array}{l}\text { - Teridentifikasi secara } \\
\text { spesifik }\end{array}$ \\
\hline
\end{tabular}

Sumber: Hasil capaian (data terolah)

\subsection{Channels}

Produk jamu herbal, didistribusikan dengan berbagai cara, dapat berupa penjualan langsung maupun online, saat ini peran pedagang perantara semakin kecil. Semakin kreatif menciptakan channel penjualan semakin besar pula peluang untuk mempopulerkan jamu herbal pada pelanggan, model-model pemasaran dengan menggunakan periklanan, promosi penjualan, hubungan masyarakat, maupun pemasaran langsung lainnya masih cukup efektif dalam pemasaran jamu herbal.

\subsection{Customer Relationships}

Jamu herbal merupakan menunjukkan bahwa dalam membangun hubungan baik petani maupun produsen jamu terhadap pelanggan. Hanya terbatas pada pola informasi dan komunikasi dengan menggunakan teknologi informasi, yang sifatnya membangun kemudahan dalam menyampaikan sesuatu kepada konsumen, tanpa dilandasi atas kompensasi ekonomi, hal ini dimungkinkan karena skala pengusahaan jamu masih terbatas.

\subsection{Key Resources}

Sumberdaya yang dimiliki dalam pengembangan industri jamu herbal cukup representatif baik sumber daya manusia maupun teknologi, dengan demikian peningkatkan skala pengembangan sangat memungkinkan dalam konteks industri.

\subsection{Key Activities}

Aplikasi penggunaan jamu herbal menghasilkan beberapa capaian, diantaranya adalah: 1). Penggunaan jamu herbal memberikan capaian yang cukup tinggi. 2) Jamu herbal bisa digunakan sebagai feed additive untuk memacu pertumbuhan ayam pedaging, dalam menggantikan antibiotic growth promoters (AGP) yang berefek negatif. 3 ) Antibiotik alami yang terkandung $\mathrm{dlm}$ jamu bisa menjadi alternatif pengganti AGP yang aman tanpa efek yang merugikan bagi keamanan pakan dan pangan. 4) Jamu herbal dalam tinjauan kesehatan, mengandung antibiotik alami serta terkandung atsiri dan kurkuminoid yang berfungsi membantu pencernaan dengan merangsang sistem syaraf untuk meningkatkan sekresi enzim2: pepsin, tripsin, lipase, amilase yang dapat meningkatkan metabolisme karbohidrat, protein, lemak, memperbaiki kecernaan, yang pada gilirannya meningkatkan performa produksi. Adapun aktivitas industri yang terstandar layak untuk terus 
dikembangkan dalam meningkatkan nilai tambah.

\subsection{Key Partnerships}

Keberhasilan jamu herbal tidak terlepas dari peran kerjasama dengan berbagai pihak, Kelembagaan kelompok petani ternak perlu dioptimalkan sebagai media untuk memudahkan koordinasi dan pengorganisasian yang terkait dengan program-program pengembangan jamu herbal.

\subsection{Cost Structures}

Biaya yang harus ditanggung oleh peatni dalam mengembangkan pakan maupun jamu organic adalah biaya penanaman, pemeliharaan, dan pemanenan yang nilainya cukup tinggi pada aktivitas produksinya. Pembiayaan terkait dengan transportasi sebagian besar dilakukan oleh pedagang pengumpul atau petani anggota kelompok yang datang sendiri kemudian mengangkut bahan pakan tersebut, yang pembiayaannya tidak terlalu tinggi, walaupun demikian hampir semua aktivitas yang dilakukan petani memerlukan pembiayaan, yang dalam penelitian ini belum dilakukan penelitian secara spesifik.

\subsection{Revenue Streams}

Aspek ini menggambarkan uang tunai yang dihasilkan, hasil usaha yang ddapatkan dalam produk turunan kegiatan PPUPIK ini yang terkait dengan usaha ayam pedaging yang dikembangkan di kampus menunjukkan bahwa perlakuan ternak yang tidak menggunakan jamu (PO) memberikan keuntungan 13, 4 persen, sedangkan perlakuan dengan menggunakan jamu 1, 2 dan 3 persen (P1, P2 dan P3) secara berurutan didapatkan keuntungan 10,39 persen, 9,39 persen dan 6,67 persen.

\section{ULASAN KARYA}

Zat pemicu pertumbuhan pada pakan akan merugikan, secara ekonomis maupun kesehatan, selain itu akan menyebabkan residu antibiotik dalam daging dan organ-organ visceral. Situasi ini sangat mungkin bisa mengganggu keamanan pangan asal daging khususnya daging unggas.[7][10]

Jamu sangat memungkinkan sebagai pengganti zat pemicu atau AGP dalam pakan ternak. Diketahui bahwa jamu bersifat alami, tanpa efek samping, karena dalam herbal terkandung berbagai zat aktif (fitobiotik), fitobiotik secara sinergi bisa merangsang enzim pencernaan endogen. Dapat pula bertindak sebagai antioksidan, agen antimikroba atau imunomodulator [11].

\section{DAMPAK DAN MANFAAT KEGIATAN}

Terbangunnya kerja sama dengan pelaku usaha dan kelompok peternak yang berorientasi pada pengembangan ternak berbasis herbal. Produk jamu herbal Siyuna dengan bahan jamu-jamuan seperti kunyit dan bahan lainnya yang digunakan untuk menghasilkan produk, juga dapat meningkatkan pemahaman dan ketrampilan mahasiswa. Budaya komersialisasi hasil penelitian dosen maupun mahasiswa juga akan terwujud serta kerja sama dengan berbagai pihak juga dapat diwujudkan.[12] 


\section{KESIMPULAN}

Pengembangan industri jamu herbal memungkinkan dikembangkan khususnya untuk ayam pedaging pada aspek potensi ekonomi dan membangun kesadaran kesehatan dalam upaya mengurangi penggunaan antibiotik yang selama ini banyak digunakan oleh peternak. Program inovasi jamu herbal untuk ternak didapatkan kesimpulan.

a. Secara ekonomi ditunjukkan bahwa hasil usaha yang didapatkan dalam produk turunan kegiatan PPUPIK ini yang terkait dengan usaha ayam pedaging menunjukkan bahwa perlakuan ternak dengan menggunakan jamu 1 persen memberikan keuntungan 10,39 persen, nilai ini lebih besar dibandingkan penggunaan jamu 2 dan 3 persen, walaupun demikian penggunaan jamu 1 persen mendapatkan keuntungan lebih rendah dibandingkan dengan usaha ayam pedaging yang tidak menggunakan jamu.

b. Indek produksi yang menjadi dasar keberhasilan aspek kesehatan menunjukkan usaha ayam pedaging tanpa menggunakan jamu memberikan nilai sebesar 390,3 yang lebih rendah dibadingkan dengan usaha ayam yang menggunakan jamu 1 persen dengan nilai 395,0

c. Penggunaan jamu sebesar 1 persen merupakan keputusan yang tepat guna mendukung keberhasilan usaha ayam pedang dalam tinjauan ekonomi dan kesehatan.

\section{PENGHARGAAN}

Kesempatan yang baik ini kami haturkan terima kasih kepada:

1. Yth. Direktur DRPM Kemenristek/ BRIN sehingga kami dapat melaksanakan program PPUPIK ini yang berorientasi pada jamu herbal untuk ternak.

2. Yth. Rektor Universitas Muhammadiyah Malang dan Direktur Direktorat Penelitian dan Pengabdian kepada Masyarakat Universitas Muhammadiyah Malang, untuk mendukung program-program pengabdian yang berorientasi pada inovasi, hilirisasi dan komersialisasi produk intelektual kampus.

\section{DAFTAR PUSTAKA}

[1] I. D. Rahayu, W. Widodo, and A. Sutanto, "The effect of fermented organic feed usage on the health status of kampong chicken," Int. J. Biosci. 2018 Int. J. Biosci., vol. 12, no. 4, pp. 35-42, 2018.

[2] C. B. Singh, K. Nongalleima, S. Brojendrosingh, S. Ningombam, N. Lokendrajit, and L. W. Singh, "Biological and chemical properties of Zingiber zerumbet Smith: a review," Phytochem Rev, vol. 11, pp. 113-125, 2012.

[3] S. Wahyuningsih, "Pengembangan Agribisnis Ditinjau dari Kelembagaan," Mediagro, vol. 3, no. 1, pp. 9-20, 2007.

[4] W. Widodo, I. D. Rahayu, and A. Sutanto, "Nutritive content assessment of organic feedstuff from 
various regions in East Java Province, Indonesia as potential exploration efforts of local poultry feed," Int. J. Biosci., vol. 12, no. 3, pp. 18-23, 2018.

[5] I. Stoilova, A. Krastanov, A. Stoyanova, P. Denev, and S. Gargova, "Antioxidant activity of a ginger extract ( Zingiber officinale )," $J$. Food Chem., vol. 102, pp. 764-770, 2007.

[6] S. Hadi, "Pengaruh Frekuensi Pemberian Tepung Temulawak (Curcuma Xanthorriza Roxb) dalam Ransum Terhadap Karkas Ayam Broiler Betina," 2010.

[7] W. M. Horhoruw and R. Rajab, "Bobot Potong, Karkas, Giblet dan Lemak Abdominal Ayam Broiler yang Diberi Gula Merah dan Kunyit dalam Air Minum Sebagai Feed Additive," Agrinimal, vol. 7, no. 2, pp. 53-58, 2019.

[8] C. Rondonuwu, J. L. P. Saerang, F. J. Nangoy, and S. Laatung, "Penambahan Rimpang Kunyit (Curcuma domestica Val.), Temulawak (Curcuma xanthorrhiza Roxb.), dan Temu Putih (Curcuma zedoaria Rosc.) dalam Ransum Komersil Terhadap Kualitas Telur
Burung Puyuh (Coturnix-Coturnix Japonica)," J. Zootek, vol. 34, no. 1, pp. 106-113, 2014.

[9] N. A. Selim, S. F. Youssef, A. F. A. Salam, and N. Sh.A, "Evaluation of Some Natural Antioxidant Source in Broiler Diets : 1-Effect on Growth, Physiological, Microbiological and Immunological Performance of Broiler Chicken," Int. J. Poult. Sci., vol. 12, no. 10, pp. 561-571, 2013.

[10] W. Widodo, I. D. Rahayu, A. Sutanto, and A. D. Anggraini, "Penambahan lempuyang dalam pakan ayam kampung super yang menggunakan campuran jamu," Semin. Nas. dan Gelar Prod., vol. 2, no. 246, pp. 469-473, 2017.

[11] V. S. Lestari, S. N. Sirajuddin, and K. Kasim, "Adoption Of Biosecurity Measures By Layer Smallholders," J. Indones. Trop.Anim.Agric., vol. 4, no. 36, pp. 297-302, 2011.

[12] I. D. Rahayu, W. Widodo, and A. Sutanto, "Produksi Pakan Organik Ayam Broiler Untuk Keamanan dan Ketahanan Pakan dan pangan Di Indonesia.," Laporan Penelitian Unggulan Perguruan Tinggi. Universitas Muhammadiyah Malang., Malang, 2015. 